\title{
INTENSIFICATION OF SYNTHESIS OF PRACTICALLY IMPORTANT MICROBIAL METABOLITES ON SUBSTRATES MIXTURE
}

\author{
T. Pirog, A. Gershtman, Yu. Penchuk \\ National University of Food Technologies
}

\begin{tabular}{l}
\multicolumn{1}{c}{ Key words: } \\
Mixture of growth \\
substrates \\
Increasing the efficiency \\
of microbial technology \\
\hline \multicolumn{1}{c}{ Article history: } \\
Received 05.07.2018 \\
Received in revised form \\
27.07.2018 \\
Accepted 31.08.2018 \\
\hline
\end{tabular}

Corresponding author:

T. Pirog

E-mail:

npnuht@ukr.net

\begin{abstract}
Cultivation of microorganisms on mixture of growth substrates allows to avoid unproductive loss of carbon and energy that occurs when using monosubstrates, and also to improve efficiency of transformation of carbon substrates into biomass and to intensify synthesis of secondary metabolites.

The paper analyzes the modern scientific literature of last two or five years concerning the increase of synthesis on the mixed substrates (including industrial waste) of primary (organic acids, lipids, enzymes), secondary (polyhydroxyalkanoates, polysaccharides, surface-active substances) metabolites, and also bioethanol and biohydrogen. Using mixture of substrates in microbial technologies enables to increase the rates of synthesis of practically valuable metabolites by $1.5-$ 10 times compared with cultivation producers on corresponding monosubstrates, and in some cases even regulate the composition and properties of final product.

Own experimental data on synthesis intensification on mixture of industrial waste (frying sunflower oil, waste of biodiesel production, molasses) of microbial exopolysaccharide ethapolan (producer Acinetobacter sp. IMV B-7005) and Nocardia vaccinii IMV B-7405 surfactants are presented. Unlike most scientists who empirically establish both the concentration of substrates in the mixture and the choice of monosubstrates, in our studies to increase the carbon transformation of substrates mixture into final product, the molar ratio of monosubstrate concentrations in mixture was established on the basis of theoretical calculations of the energy requirement for process biosynthesis. In addition, using mixture of waste to obtain microbial surfactants will not only reduce cost of final product, but also utilize toxic industrial waste and increase profitability of biodiesel production.
\end{abstract}

DOI: $10.24263 / 2225-2924-2018-24-4-6$ 


\title{
ІНТЕНСИФІКАЦІЯ СИНТЕЗУ ПРАКТИЧНО ВАЖЛИВИХ МІКРОБНИХ МЕТАБОЛІТІВ НА СУМІШІ СУБСТРАТІВ
}

\author{
Т.П. Пирог, А.Ю. Герштман, Ю.М. Пенчук \\ Національний університет харчових технологій
}

Культивування мікроорганізмів на суміші ростових субстратів дає змогу уникнути непродуктивних витрат вуглецю та енергії, які мають місце при використанні моносубстратів, а також підвищити ефективність трансформації вуглецю субстратів у біомасу та інтенсифікувати синтез вторинних метаболітів.

У статті проаналізовано сучасну наукову літературу останніх двохn'яти років щодо підвищення синтезу на змішаних субстратах (у тому числі й промислових відходах) первинних (органічні кислоти, ліпіди, ферменти), вторинних (полігідроксиалканоати, полісахариди, поверхнево-активні речовини) метаболітів, а також біоетанолу $і$ біоводню. Використання суміші субстратів у мікробних технологіях дає змогу збільшити показники синтезу практично иінних метаболітів у 1,5-10 разів порівняно з вирощуванням продуцентів на відповідних моносубстратах, а також у деяких випадках навіть регулювати склад і властивості ицільового продукту.

Наведено власні експериментальні дані про інтенсифікацію синтезу на суміші промислових відходів (відпрачьована сонямникова олія, відходи виробництва біодизелю, меляса) мікробного екзополісахариду етаполану (продуцент Acinetobacter sp. IMB B-7005) і поверхнево-активних речовин Nocardia vaccinii IMB B-7405. На відміну від більшості науковців, які емпірично встановлюють як конщентрацію субстратів у суміші, так $i$ вибір моносубстратів, у наших дослідженнях для підвищення трансформаиії вуглецю суміші субстратів у иільовий продукт встановлювали оптимальне для його утворення молярне співвідношення конщентрачій моносубстратів у сумімі на основі теоретичних розрахунків енергетичних потреб процесу біосинтезу. Крім того, використання суміші відходів для одержання мікробних ПАР дасть змогу не тільки знизити собівартість иільового продукту, а й утилізувати токсичні промислові відходи та підвищити рентабельність виробництва біодизелю.

Ключові слова: суміш ростових субстратів, підвищення ефективності мікробних технологій.

Постановка проблеми. Нині технології мікробного синтезу найінтенсивніше розвиваються серед багатьох галузей біотехнології. Практично цінні мікробні метаболіти поступово заміщують традиційні продукти, а в інших випадках є унікальними і не можуть бути отримані хімічним синтезом [1].

Основними недоліками для великомасштабного виробництва більшості продуктів мікробного синтезу є їх собівартість, зумовлена використанням дорогих субстратів і невисокий вихід кінцевого продукту. Тому для розвитку економічно ефективних технологій застосовуються різноманітні підходи: 
використання як субстратів відходів інших виробництв, оптимізація умов культивування продуцентів, внесення у середовище екзогенних попередників біосинтезу, визначення можливих «вузьких» місць метаболізму і розробка шляхів їхнього усунення, а також використання суміші ростових і неростових субстратів [2].

Відомо, що використання суміші субстратів дає змогу значно підвищити синтез біомаси, а можливість інтенсифікації синтезу вторинних метаболітів вперше було встановлено на прикладі мікробного екзополісахариду етаполану [2]. За одночасного споживання суміші субстратів мікроорганізмами часто спостерігають підвищення рівня біомаси, швидкості росту, скорочення тривалості лагфази, що можуть бути зумовлені: 1) використанням одного з субстратів як додаткового джерела енергії; 2) одночасним використанням обох субстратів як в енергетичному, так і в конструктивному метаболізмі; 3) розширенням «вузьких місць» метаболізму моносубстрату за рахунок введення допоміжного субстрату [2].

У 2013 р. ми опублікували літературний огляд [3], у якому були підсумовані відомі на той час дані про використання мікроорганізмами суміші ростових субстратів як у природних умовах, так і керованих біотехнологічних процесах. Велика увага була приділена молекулярним механізмам, що лежать в основі явища катаболітної репресії у мікроорганізмів і їх використанню для розробки технологій утилізації рослинної біомаси з одержанням промислово важливих метаболітів, а також стратегії виживання гетеротрофних мікроорганізмів у природних оліготрофних середовищах.

Незважаючи на досить короткий проміжок часу від моменту публікації огляду [3], у літературі з'явилися нові відомості про синтез мікробних метаболітів на суміші субстратів, причому й на змішаних промислових відходах.

3 огляду на вищевикладене мета цього огляду - аналіз сучасної наукової літератури про підвищення синтезу різноманітних продуктів мікробного походження на змішаних субстратах, яка з'явилась після опублікування літературного огляду [3] або не увійшла до нього.

Синтез поверхнево-активних речовин на суміші субстратів. Зазначимо, що в останні кілька років, як і раніше, інформація про використання змішаних субстратів для утворення мікробних поверхнево-активних речовин (ПАР) є обмеженою [4-13].

Софороліпіди. У [4] зазначається, що використання суміші гідрофобних і гідрофільних субстратів для біосинтезу ПАР дріжджами є більш ефективним, ніж культивування продуцентів на відповідних моносубстратах. Так, максимальну концентрацію біомаси (27 г/л) та софороліпіду (38,6 г/л) штам Starmerella bombicola MTCC 1910 утворював на суміші глюкози (100 г/л) та соняшникової олії (100 г/л). Ці показники були на 45\% вищими, ніж на моносубстраті глюкозі, а на середовищі з олією утворювались лише сліди софороліпідів.

Інший штам дріжджів Wickerhamiella domercqiae CGMCC 1576 синтезував софороліпіди на суміші олеїнової кислоти (6\%) та глюкози (80 г/л) [6]. Максимальна концентрація ПАР (41 г/л) досягалася після 144 год культивування.

У [10] повідомляється, що вихід ПАР вдалося підвищити майже в 10 разів (до 20г/100г субстрату) у разі культивування штаму Candida bombicola NRRL 
Y-17069 на суміші шроту від виробництва соняшникової олії (50 г/л) та нерафінованої соєвої олії (50 г/л). У подальших дослідженнях автори здійснювали поверхневе культивування продуцента на такому самому змішаному субстраті, що супроводжувалося збільшенням виходу софороліпідів до 49,5Г/100г субстрату. В [11] штам NRRL Y-17069 культивували на суміші відпрацьованого моторного мастила $(50$ г/л) та відходів від виробництва соняшникової олії (50 г/л). Максимальна концентрація синтезованих ПАР (26,4 г/л, або 13,2г/100г субстрату) досягалась після 96 год культивування. Як i в [10], при зміні способу культивування з глибинного на поверхневий, вихід цільового продукту вдалося збільшити до 45,8г/100г субстрату.

Daverey зі співавт. [12] досліджували синтез софороліпідів дріжджами Candida bombicola NRRL Y-17069 на суміші депротеїнізованої сироватки (90 г/л), глюкози (10 г/л) та олеїнової кислоти (100 г/л). Концентрація ПАР становила 23,3 г/л, у той час як на середовищі без глюкози була на 56\% нижчою. Встановлено, що показники біосинтезу залежали від співвідношення вмісту глюкози та сироватки в середовищі культивування. Так, максимальна кількість софороліпідів досягалась за співвідношення концентрацій сироватки і глюкози 9:1. Під час культивування штаму NRRL Y-17069 у ферментері на середовищі такого самого складу кількість ПАР становила 25,5 г/л, а регуляція $\mathrm{pH}$ в процесі культивування дозволила збільшити цей показник до 33,3 г/л. Крім того, заміна олеїнової кислоти на дешевші соняшникову та оливкову олію супроводжувалася зниженням концентрації ПАР до 2,6 та 6,2 г/л відповідно. У [12] зазначається, що необхідність стадії депротеїнізації молочної сироватки значно знижує ефективність даної технології.

Інші гліколіпіди. У [5] повідомляється, що штам дріжджів Pichia caribbica на середовищі з 100 г/л ксилози та 4\% олеїнової кислоти синтезував 7,48 г/л ксилоліпідів.

Faria iз співавт. [7] досліджували можливість використання ксилози як моносубстрату, так і в суміші з глюкозою для біосинтезу манозилеритритоліпідів дріжджами Pseudozyma antarctica PYCC 5048T, Pseudozyma rugulosa PYCC 5537T, Pseudozyma aphidis PYCC 5535T. Лише у разі культивування штаму РYСС 5535T на суміші субстратів концентрація ПАР була удвічі вищою, ніж на моносубстраті ксилозі [7].

У [8] п'ять штамів дріжджів культивували на суміші глюкози з гліцерином, соєвою олією, оливковою олією та відходами після її виробництва. Максимальна концентрація гліколіпідів (2,6 г/л) досягалася за культивування штаму Wickerhamomyces anomalus CCMA 0358 в середовищі, що містило суміш глюкози (1 г/л) та оливкової олії (20 г/л).

Karpenko iз співавт. [9] повідомляють про біосинтез рамноліпідів штамом Pseudomonas sp. PS-17 на суміші гліцерину з пересмаженою олією та відходами виробництва соняшникової олії. Концентрація ПАР, синтезованих на суміші гліцерину з відходами виробництва соняшникової олії, була на 30$70 \%$ вищою, ніж на моносубстратах. У разі використання суміші гліцерину 3 пересмаженою олією показники синтезу були на $20 \%$ вищими, ніж на гліцерині. Максимальна концентрація рамноліпідів $(10,5$ г/л) досягалась за умов росту продуцента в середовищі з 30 г/л гліцерину та 15 г/л відходів вироб- 
ництва соняшникової олії. Проте зазначимо, що синтез ПАР досліджувався не на «класичній» суміші субстратів, оскільки відходи виробництва олії вносили у середовище після 72 год культивування.

Лinonenтиди. Заслуговує на увагу дослідження [13], в якому описано процес виділення штамів мікроорганізмів, здатних до автотрофної фіксації вуглецю. Автори повідомляють про культивування ізольованих штамів упродовж 8 діб у простому мінеральному середовищі з 50 мМ NaHCO 3 і 1\% глюкози як джерелами вуглецю. Встановлено, що штам Bacillus sp. SS105 виявився автотрофом і здатним до синтезу ПАР ліпопептидної природи. За умов росту на середовищі з $50 \mathrm{mM} \mathrm{NaHCO} 3$ як автотрофним джерелом вуглецю та мелясою (15\% об’ємна частка) штам SS105 синтезував 2,65 г/л ПАР. Автори зазначають, що в подальшому розробка такої технології одержання ПАР дасть змогу утилізувати вуглекислий газ, що накопичується в земній атмосфері.

Зазначимо, що використання суміші субстратів є доцільним лише за умови, коли концентрація ПАР, синтезованих на суміші субстратів, є порівняною з показниками на моносубстратах. Проте автори праць $[5,6,8,11,13]$ не наводять таких даних, а у працях $[4,10]$ моносубстрати та їх суміші не були еквімолярні за вуглецем, що ставить під сумнів ефективність такої технології.

Крім того, у [4-13] дослідники емпірично визначали концентрацію субстратів у суміші. За таких умов підвищення показників синтезу цільових продуктів на суміші субстратів навіть у рази порівняно 3 культивуванням на моносубстратах не є показовим, адже основним критерієм ефективності змішаних субстратів $\epsilon$ максимальна конверсія вуглецю в цільовий продукт.

У зв'язку з цим для біосинтезу ПАР штамом Nocardia vaccinii IMB B-7405 ми здійснювали попередній теоретичний розрахунок співвідношення концентрацій моносубстратів (гліцерин та глюкоза) у суміші [14]. Згідно з «енергетичною» класифікацією субстратів Бабеля [2] гліцерин є енергетично дефіцитним субстратом, а глюкоза залежно від шляху катаболізму може бути або енергетично дефіцитним (гліколіз, шлях Ентнера-Дудорова), або енергетично надлишковим (пентозофосфатний цикл). У подальших дослідженнях було встановлено, що у штаму IMB В-7405 глюкоза залучається до метаболізму через пентозофосфатний цикл. На основі теоретичних розрахунків було встановлено, що молярне співвідношення концентрацій глюкози і гліцерину в середовищі повинно становити 0,394:1, або 1:2,5 [14]. Експериментальні дослідження підтвердили теоретичні розрахунки. Максимальний синтез ПАР спостерігався за співвідношення компонентів суміші 1:2,5-1,4, що є близьким до теоретично розрахованого значення.

На наступному етапі [15] глюкозу та очищений гліцерин замінювали на відповідні промислові відходи (мелясу та технічний гліцерин, який є відходом виробництва біодизелю). За умов росту штаму IMB В-7405 на середовищі з 5\% технічного гліцерину та 1\% меляси концентрація ПАР досягала 6,4 г/л. Подальше збільшення концентрації будь-якого 3 компонентів суміші призводило до зниження концентрації цільового продукту, що було спричинене недостатнім співвідношенням C/N у середовищі. Тому на наступному етапі у середовищі з 5-7\% технічного гліцерину підвищували удвічі (до 1 г/л) концен- 
трацію джерела азоту. Такий прийом дав змогу підвищити концентрацію ПАР до 7,5 г/л [15].

Подальші дослідження показали можливість інтенсифікації синтезу ПАР N. vaccinii IMB В-7405 на суміші токсичних промислових відходів (відпрацьованої соняшникової олії та технічного гліцерину). Спочатку на основі теоретичних розрахунків енергетичних потреб синтезу поверхнево-активних трегалозоміколатів і біомаси $N$. vaccinii IMB B-7405 на енергетично дефіцитному субстраті (гліцерин) встановлено, що молярне співвідношення концентрацій рафінованої соняшникової олії та очищеного гліцерину у суміші, за якого досягається максимальний синтез ПАР, повинно становити 0,16:1. Експериментальні дослідження показали, що найвищі показники синтезу ПАР спостерігалися за молярних співвідношень концентрацій цих субстратів $0,14: 1-0,19: 1$, максимально наближених до теоретично розрахованого. Далі рафіновану олію і очищений гліцерин замінювали на відповідні промислові відходи. За молярного співвідношення концентрацій відпрацьованої олії та технічного гліцерину 0,078:1 у суміші (з урахуванням 50\% вмісту гліцерину у складі відходів виробництва біодизелю) та використання інокуляту, вирощеного на технічному гліцерині, кількість синтезованих ПАР становила 5,1-5,4 г/л, що в 1,6-2,3 раза вище порівняно з культивуванням $N$. vaccinii IMB B-7405 на відповідних моносубстратах

Узагальнені дані про синтез поверхнево-активних речовни на змішаних субстратах наведено у табл. 1.

Таблиия 1. Використання суміші субстратів для біосинтезу поверхнево-активних речовин

\begin{tabular}{|c|c|c|c|c|c|}
\hline ПАР & Продуцент & $\begin{array}{c}\text { Суміш } \\
\text { субстратів, г/л }\end{array}$ & $\begin{array}{c}\text { Концентація } \\
\text { ПАР, г/л }\end{array}$ & $\begin{array}{c}\text { Зміна } \\
\text { концентрації } \\
\text { ПАР (г/л) від } \\
\text { контролю*, \% }\end{array}$ & Література \\
\hline 1 & 2 & 3 & 4 & 5 & 6 \\
\hline \multirow{5}{*}{ Софороліпіди } & \multirow{2}{*}{$\begin{array}{c}\text { Starmerella } \\
\text { bombicola MTCC } \\
1910\end{array}$} & \multirow{2}{*}{$\begin{array}{c}\text { глюкоза, } 100+ \\
\text { рафінована } \\
\text { соняшникова } \\
\text { олія, } 100\end{array}$} & \multirow[b]{2}{*}{38,6} & глюкоза, 145 & \multirow[b]{2}{*}{ [4] } \\
\hline & & & & $\begin{array}{c}\text { соняшникова } \\
\text { олія, } 1600\end{array}$ & \\
\hline & $\begin{array}{l}\text { Wickerhamiella } \\
\text { domercqiae } \\
\text { CGMCC } 1576\end{array}$ & \begin{tabular}{|c|} 
глюкоза, $80+$ \\
олеїнова кислота, \\
6\% (об'ємна \\
частка) \\
\end{tabular} & 41 & 一 & [6] \\
\hline & \multirow{2}{*}{$\begin{array}{c}\text { Candida } \\
\text { bombicola } \text { NRRL } \\
\text { Y-17069 }\end{array}$} & \begin{tabular}{|c|} 
шрот від вироб- \\
ництва соняш- \\
никової олії, 50 + \\
нерафінована \\
соєва олія, 50 \\
\end{tabular} & $\begin{array}{c}20 \Gamma / 100 \Gamma \\
\text { субстрату }\end{array}$ & шрот, 1000 & {$[10]$} \\
\hline & & \begin{tabular}{|c|} 
відпрацьоване \\
моторне масти- \\
ло, $50+$ відходи \\
виробництва \\
соняшникової \\
олії, 50
\end{tabular} & 26,4 & 一 & [11] \\
\hline
\end{tabular}




\begin{tabular}{|c|c|c|c|c|c|}
\hline & & & & \multicolumn{2}{|c|}{ Продовження табл. 1} \\
\hline 1 & 2 & 3 & 4 & 5 & 6 \\
\hline Софороліпіди & $\begin{array}{c}\text { Candida } \\
\text { bombicola } \text { NRRL } \\
\text { Y-17069 }\end{array}$ & $\mid \begin{array}{c}\text { депротеїнізована } \\
\text { сироватка, } 90+ \\
\text { глюкоза, } 10+ \\
\text { олеїнова кислота, } \\
100\end{array}$ & 23,3 & $\begin{array}{c}\text { середовище } \\
\text { без глюкози, } \\
156\end{array}$ & {$[12]$} \\
\hline $\begin{array}{c}\text { Інші } \\
\text { гліколіпіди }\end{array}$ & Pichia caribbica & $\mid \begin{array}{c}\text { ксилоза, } 100+ \\
\text { олеїнова кислота, } \\
4 \% \text { (об'ємна } \\
\text { частка) }\end{array}$ & 7,48 & - & {$[5]$} \\
\hline \multirow{10}{*}{$\begin{array}{c}\text { Інші } \\
\text { гліколіпіди }\end{array}$} & \multirow{2}{*}{$\begin{array}{c}\text { Pseudozyma } \\
\text { antarctica } \text { PYCC } \\
5048 \mathrm{~T}\end{array}$} & \multirow{6}{*}{$\begin{array}{l}\text { глюкоза, } 20+ \\
\text { ксилоза, } 20\end{array}$} & \multirow[b]{2}{*}{4,9} & ксилоза, 102 & \multirow{6}{*}[7]{} \\
\hline & & & & глюкоза, 91 & \\
\hline & \multirow{2}{*}{$\begin{array}{c}\text { Pseudozyma } \\
\text { rugulosa } \mathrm{PYCC} \\
5537 \mathrm{~T} \\
\end{array}$} & & \multirow[b]{2}{*}{3,0} & ксилоза, 107 & \\
\hline & & & & глюкоза, 91 & \\
\hline & \multirow{2}{*}{$\begin{array}{c}\text { Pseudozyma } \\
\text { aphidis PYCC } \\
5535 T \\
\end{array}$} & & \multirow[b]{2}{*}{2,2} & ксилоза, 208 & \\
\hline & & & & глюкоза, 74 & \\
\hline & \begin{tabular}{|c} 
Wickerhamomyces \\
anomalus CCMA \\
0358 \\
\end{tabular} & $\begin{array}{c}\text { глюкоза, } 1+ \\
\text { оливкова олія, } 20\end{array}$ & 2,6 & - & {$[8]$} \\
\hline & \multirow{3}{*}{$\begin{array}{c}\text { Pseudomonas sp. } \\
\text { PS-17 }\end{array}$} & $\begin{array}{c}\text { гліцерин, } 30+ \\
\text { пересмажена } \\
\text { олія, } 15\end{array}$ & 9,7 & гліцерин, 120 & \multirow{3}{*}[9]{} \\
\hline & & \multirow{2}{*}{$\begin{array}{c}\text { гліцерин, } 30+ \\
\text { відходи вироб- } \\
\text { ництва соняш- } \\
\text { никової олії, } 15\end{array}$} & \multirow[b]{2}{*}{10,5} & гліцерин, 130 & \\
\hline & & & & відходи, 170 & \\
\hline Ліпопептид & $\begin{array}{l}\text { Bacillus sp. } \\
\quad \text { SS105 }\end{array}$ & $\mid \begin{array}{c}\mathrm{NaHCO}_{3}, 50 \mathrm{mM} \\
\text { (автотрофне дже- } \\
\text { рело вуглецю), + } \\
\text { меляса, 15\% } \\
\text { (об’ємна частка) }\end{array}$ & 2,65 & 一 & [13] \\
\hline $\begin{array}{c}\text { Трегалозоміко } \\
\text { лат }\end{array}$ & $\begin{array}{l}\text { Nocardia vaccinii } \\
\text { IMB B-7405 }\end{array}$ & $\begin{array}{c}\text { технічний } \\
\text { гліцерин, 7\% } \\
\text { (об’ємна частка) } \\
\text { + меляса, 1\% } \\
\text { (об’ємна частка) }\end{array}$ & 7,5 г/л & $\begin{array}{c}\text { технічний } \\
\text { гліцерин, } 320 \\
\text { меляса, } 290\end{array}$ & {$[15]$} \\
\hline
\end{tabular}

Примітки: *контроль (100\%) показники синтезу на моносубстратах; «—»— дані не наведено.

Біосинтез інших мікробних метаболітів на змішаних субстратах. Стратегія використання суміші субстратів використовується не лише для отримання ПАР, а й для інших практично цінних мікробних метаболітів: ліпідів [16-24], екзополісахаридів [25-27], пілігідроксиалканоатів [28-30], ферментів [31-33], органічних кислот [34-38], пропандіолу [39, 40], біоетанолу [41], біоводню [42, 43].

Ліпіди. Продуктивність синтезу ліпідів старою та молодою культурою гетеротрофних мікроводоростей Chlorella protothecoides на середовищі з глю- 
козою та дріжджовим екстрактом становила 2,07 і 1,61 г/л/добу відповідно, у той час як при використанні суміші відходів пивоваріння і технічного гліцерину цей показник підвищувався до 2,12 і 1,81 г/л/добу [16]. У праці [17] показано, що використання суміші апельсинового жому та відходу біодизельного виробництва для синтезу метану зменшує інгібуючий вплив компонентів цих субстратів і забезпечує правильний баланс поживних речовин.

Аналогічний підхід було використано Louhasakul та Cheirsilp [18]. Змішування слабкокислих стічних вод після виробництва пальмової олії та лужного технічного гліцерину дало змогу виключити використання титрувальних агентів для доведення $\mathrm{pH}$ до оптимального рівня, а кількість синтезованих ліпідів Yarrowia lipolytica TISTR 5151 була у 1,55 раза більшою, ніж під час росту дріжджів тільки на відходах виробництва пальмової олії [18].

У [19] використовували суміші летких жирних кислот для біосинтезу мікробних ліпідів штамом Cryptococcus curvatus ATCC 20509. Максимальна концентрація ліпідів (4,93 г/л) та біомаси $(8,68$ г/л) спостерігалась за використання суміші оцтової, пропіонової і масляної кислот у співвідношенні (г/л) 15:5:10, та була вищою ніж на середовищі 330 г/л оцтової кислоти як моносубстрату (концентрація ліпідів 4,18 г/л та біомаси 7,21 г/л. Ці ж автори для біосинтезу ліпідів на суміші жирних кислот використовували інший штам Cryptococcus curvatus MUCL 29819 [20]. Як і в попередніх дослідженнях [19], найбільший вплив на конентрацію синтезованих ліпідів спричиняв вміст оцтової кислоти у суміші жирних кислот. Так, максимальна концентрація ліпідів $(1,77$ г/л) та біомаси $(4,4$ г/л) досягалася на суміші (г/л) оцтової, пропіонової і масляної кислот у співвідношенні 6:3:1.

Ganatsios із співавт. [21] досліджували синтез ліпідів Lipomyces starkeyi DSM 70296 на суміші меляси та апельсинового соку з загальною концентрацією вуглеводів 40 г/л. Встановлено, що за таких умов культивування концентрація ліпідів становила 0,25 г/г біомаси та була вищою, ніж за використання 40 г/л глюкози як єдиного джерела вуглецю (0,23 г/г біомаси).

Автори дослідження [22] зазначають, що у процесі культивування Rhodosporidium toruloides DSMZ 4444 на суміші 30 г/л глюкози та 30 г/л гліцерину спостерігали типову диауксію, тому концентрація синтезованих ліпідів (11 г/л) практично не відрізнялася від такої на моносубстраті глюкозі.

У [23] для біосинтезу ліпідів штамом дріжджів Wickerhamomyces anomalus використовували суміш глюкози та відпрацьованої після смаження картоплі, риби та м'яса олії. Автори зазначають, що додавання відпрацьованих олій призвело до зниження загального вмісту накопичуваних ліпідів, проте на 47\% підвищило концентрацію біомаси.

У [24] описується синтез штамом дріжджів Yarrowia lipolytica JMY4086 ліпідів на суміші меляси та технічного гліцерину. На початку культивування в поживному середовищі містилась лише меляса, за рахунок якої відбувалось накопичення біомаси продуцента. На 48 год починали додавати технічний гліцерин зі швидкістю 8 г/год до загального вмісту в середовищі 100 г/л. Максимальна концентрація ліпідів накопичувалась після 100 год культивування та становила 16 г/л. 
Екзополісахариди. У [25] досліджували синтез пулулану на суміші гідролізату картопляного крохмалю з сахарозою, глюкозою, фруктозою. Під час культивування Aureobasidium pululans 201253 у ферментері на середовищі 3 80 г/л крохмалю і 20 г/л сахарози концентрація пулулану становила 55 г/л та була вищою, ніж на моносубстраті крохмалі (35 г/л) та суміші крохмалю, глюкози та фруктози (39 г/л), проте нижчою, ніж за використання сахарози як моносубстрату (69 г/л). Автори зазначають, що попри те, що оптимальним субстратом для біосинтезу пулулану є сахароза, використання суміші сахарози і гідролізату крохмалю дасть змогу знизити собівартість кінцевого продукту.

У праці [26] встановлено, що у процесі вирощування Leuconostoc mesenteroides DSM 20343 на середовищі, що містило суміш соєвого борошна (або борошна фави) з сахарозою суттєво підвищувалася в'язкість культуральної рідини, що засвідчує підвищення рівня синтезу екзополісахаридів (глюкану та фруктану) порівняно з іншими метаболітами (манітол, молочна та оцтова кислота).

Наші дослідження [27] дали змогу встановити умови культивування Acinetobactersp. IMB B-7005, які б забезпечували максимальні показники синтезу мікробного екзополісахариду (ЕПС) етаполану на суміші меляси та соняшникової олії. На основі теоретичних розрахунків енерговитрат на синтез етаполану та біомаси визначено, що оптимальне молярне співвідношення концентрацій енергетично дефіцитного (сахароза) та надлишкового (соняшникова олія) субстратів у суміші становить 1:0,9. Експерименти показали, що найвищі показники синтезу ЕПС спостерігалися за молярного співвідношення моносубстратів у суміші 1:1,1, максимально наближеного до теоретично розрахованого. Підвищення концентрації меляси та рафінованої олії у суміші з 1,0 до $1,5 \%$ супроводжувалося збільшенням кількості синтезованих ЕПС і ЕПСсинтезувальної здатності у 1,2 і 1,3 раза відповідно. Встановлено можливість заміни рафінованої олії у суміші з мелясою на різні типи відпрацьованої (після смаження картоплі, м'яса, овочів та змішану). Найвищі показники синтезу ЕПС (концентрація ЕПС 14 г/л, ЕПС-синтезувальна здатність 3,5 г ЕПС/г біомаси) спостерігалися за умови використання змішаної відпрацьованої олії як для одержання посівного матеріалу, так і біосинтезу ЕПС [27]. Одержані нами результати засвідчують можливість створення універсальної технології одержання мікробного екзополісахариду етаполану на суміші відходів (меляси та відпрацьованої олії), незалежної від типу та постачальника відпрацьованої олії.

Полігідроксиалканоати. Одним із відомих і широко використовуваних мікробних полімерів є полігідроксиалканоати (ПГА). Завдяки високій біосумісності та біодеградабельності такі полімери широко використовуються в різних сферах діяльності людини [28]. Так, сополімер полі(3-гідроксибутират-со-4-гідроксибутират) [Р(3НB-со-4НВ)] застосовується у фармацевтиці та як біоматеріал в медицині. Унікальні властивості цього сополімеру зумовлені наявністю у його складі мономеру 4-гідроксибутирату (4НВ), оскільки він не спричиняє запалення тканин, підвищує загальну біосумісність та покращує фізичні властивості кінцевого продукту. Тож зусилля науковців спрямовані не лише на інтенсифікацію синтезу полімеру, а й на збільшення вмісту в ньому мономеру 4-гідроксибутирату (4НВ). 
Одним із продуцентів сополімеру [Р(3НВ-со-4НВ)] є штам бактерій Сирriavidus sp. USMAA1020 [28]. Як субстрати для біосинтезу використовували суміш олеїнової кислоти з попередниками 4-гідроксибутирату (4НВ) $(\gamma$-бутиролактон, 1,4-бутандіол, 1,6-гександіол) та суміші лише попередників мономеру. Встановлено, що за використання суміші олеїнової кислоти з кожним із попередників концентрація синтезованого сополімеру збільшилась в 3-8 разів, але при цьому вміст мономеру 4-гідроксибутирату (4НВ) у складі цільового продукту знизився на $40-50 \%$ порівняно з сополімером, одержаним на середовищі з попередниками 4-гідроксибутирату як моносубстратах.

Тому на наступному етапі досліджень автори досліджували синтез сополімеру [P(3НB-со-4HB)] лише на суміші попередників 4-гідроксибутирату. За таких умов культивування концентрація синтезованого сополімеру була на $30-50 \%$ нижчою, ніж за використання суміші попередників мономеру 4НВ та олеїнової кислоти, проте вміст цільового мономеру у складі сополімеру підвищувався до 50-70\%, що у $2-2,5$ раза більше ніж на відповідних попередниках як моносубстратах. Сополімер з максимальним вмістом (70\%) цільового мономеру був отриманий на суміші $\gamma$-бутиролактону та 1,6 -гександіолу, проте концентрація синтезованого полімеру становила лише 0,3 г/л. Отже, більш оптимальним варіантом $є$ використання суміші 1,4-бутандіолу i 1,6-гександіолу, що дає можливість отримати 5,4 г/л сполімеру з вмістом 4НВ 40\% [28]. У наступних дослідженнях [29] автори встановили можливість підвищення концентрації синтезованого на суміші 1,4-бутандіолу і 1,6-гександіолу сополімеру до 8,6 г/л (вміст 4НВ 35\%). Крім того, у [30] було показано можливість отримання сополімеру на суміші $\gamma$-бутиролактону та 1,6-гександіолу з вмістом 4НВ 92\% за рахунок використання генно модифікованих

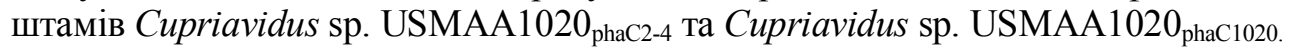

Ферменти. Salakkam iз співавт. [31] використовували суміш макухи соєвих бобів і відвареного рису як субстрату для твердо-фазової ферментації Aspergillus oryzae TISTR 3087. За масового співвідношення макухи соєвих бобів з відвареним рисом 75:25 активність протеази становила 33 од/г, що у 11 раз більше, ніж за використання соєвих бобів як моносубстрату.

У [32] досліджували синтез ліпази штамом Yarrowia lipolytica SM7 на суміші технічного гліцерину (40 г/л) 3 оливковою та соєвою олією (5\% мас). Як зазначають автори, додавання олійних субстратів дало змогу зняти репресію синтезу ліпази гліцерином та інтенсифікувати ії утворення. Так, на суміші субстратів активність ліпази становила 22,45-25,1 од/мл, у той час як на моносубстраті гліцерині всього 4 од/мл.

Максимальний синтез фітази (1881,26 од/г міцелію) Sporotrichum thermophile досягався на середовищі з 2,5\% Tween 80 i 1,0\% дріжджового екстракту [33]. У той же час під час культивування продуцентана суміші цукрової тростини $\mathrm{i}$ пшеничних висівок вдалося підвищити активність ферменту в 11,6 раза.

Органічні кислоти. Zheng зі співавт. [34] повідомляють про використання залишків Софори жовтуватої (Sophora flavescens) у суміші з змішаними харчовими відходами для біосинтезу $L$-молочної кислоти Lactobacillus casei CICC 6106. Максимальна концентрація $L$-молочної кислоти становила 48,4 г/л за 
співвідношення софори і змішаних харчових відходів 1:1,5 і була в 2-4 рази вищою, ніж на відповідних моносубстратах.

Propionibacterium acidipropionici CGMCC1.2225 [35] синтезував 21,9 г/л пропіонової кислоти на суміші гліцерину та глюкози у молярному співвідношенні 4:1. За умов росту штаму на моно субстратах концентрація цільового продукту не перевищувала $11,5-18,1$ г/л.

Автори праці [32] повідомляють про синтез штамом Y. lipolytica SM7 лимонної кислоти на суміші технічного гліцерину (40 г/л) 3 оливковою, соєвою олією та моторним мастилом (5\% мас.). Встановлено, що використання суміші технічного гліцерину з оливковою та соєвою олією збільшувало концентрацію цитрату на 41 та 90\% відповідно. Максимальна концентрація лимонної кислоти $(2,3$ г/л) досягалася на суміші технічного гліцерину та соєвої олії. Додавання ж до технічного гліцерину моторного мастила знижувало концентрацію цільового продукту на $58 \%$.

Candida viswanathii ipe-1 синтезує $\alpha, \omega$-додекандіонову кислоту на суміші ксилози і глюкози [36]. Здатність штаму до одночасного споживання гексоз і пентоз дала змогу розробити авторам ефективний процес біосинтезу $\alpha, \omega-$ додекандіонової кислоти на суміші гідролізату соломи та н-додекану. За таких умов культивування концентрація цільового продукту була на $40 \%$ вищою, ніж на моносубстраті глюкозі.

У [37] досліджували синтез бурштинової кислоти за умов росту Enterobacter sp. LU1 на суміші гліцерину і лактози. Концентрація сукцинату становила 35 г/л за вмісту гліцерину і лактози у суміші 50 і 25 г/л відповідно.

У процесі вирощування Rhizopus sp. IAFB781 на середовищі 340 г/л гліцерину або ксилози концентрація фумарової кислоти становила 6,1 і 19,8 г/л відповідно [38]. У той же час використання суміші цих субстратів дало змогу підвищити концентрацію цільового продукту до 28 г/л.

Пропандіол. У [39] автори повідомляють про синтез 1,3-пропандіолу штамом Klebsiella pneumoniae BA11 на суміші гліцерину та глюкози. Проте зазначається, що додавання глюкози в середовище культивування не вплинуло на концентрацію синтезованого цільового продукту, а лише збільшило на $3-5 \%$ концентрацію біомаси порівняно з культивуванням продуцента на гліцерині.

Використання глюкози, ксилози та арабінози як ко-субстратів при культивуванні Clostridium diolis DSM 15410 на середовищі з гліцерином супроводжувалося збільшення виходу 1,3-пропандіолу (1,3-ПД) на 28\%, 19\% і 18 \% відповідно [40]. Під час росту штаму DSM 15410 на гліцерині і суміші цукрів (глюкози, ксилози, арабінози у масовому співвідношення 1:1:1) також спостерігали підвищення на 19\% (до 13,9 г/л) концентрації 1,3-ПД, що свідчить про можливість використання суміші гліцерину та лігноцелюлозних гідролізатів для отримання 1,3-ПД. Це припущення було підтверджене експериментально: за культивування $C$. diolis DSM 15410 на суміші технічного гліцерину та гідролізату кукурудзяних стебел рівень синтезу 1,3-ПД становив 42,9 г/л, що на $31 \%$ вище, ніж під час росту на гліцерині як моносубстраті [40].

Узагальнені дані про утворення різних продуктів мікробного синтезу на змішаних субстратах наведено у табл. 2. 
Таблиия 2. Використання суміші субстратів для біосинтезу практично цінних метаболітів

\begin{tabular}{|c|c|c|c|c|c|}
\hline $\begin{array}{c}\text { Цільовий } \\
\text { продукт }\end{array}$ & Продуцент & $\begin{array}{c}\text { Суміш } \\
\text { субстратів, г/л }\end{array}$ & $\begin{array}{c}\text { Показники } \\
\text { синтезу }\end{array}$ & \begin{tabular}{|c|} 
Зміна \\
показників \\
синтезу \\
порівняно 3 \\
контролем*, \% \\
\end{tabular} & Література \\
\hline 1 & 2 & 3 & 4 & 5 & 6 \\
\hline \multirow{7}{*}{ Ліпіди } & \begin{tabular}{|c} 
Cryptococcus \\
curvatus ATCC \\
20509
\end{tabular} & \begin{tabular}{|c|} 
оцтова \\
кислота, $15+$ \\
пропіонова \\
кислота, 5+ \\
масляна \\
кислота, 10 \\
\end{tabular} & 4,93 г/л & 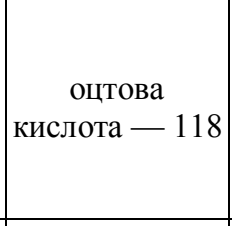 & [19] \\
\hline & $\begin{array}{c}\text { Cryptococcus } \\
\text { curvatus } \\
\text { MUCL } 29819\end{array}$ & \begin{tabular}{|c|} 
оцтова \\
кислота, $2,4+$ \\
пропіонова \\
кислота, $1,2+$ \\
масляна \\
кислота, 0,4 \\
\end{tabular} & 1,77 г/л & - & [20] \\
\hline & $\begin{array}{c}\text { Lipomyces } \\
\text { starkeyi DSM } \\
70296\end{array}$ & $\begin{array}{c}\text { меляса+апельс } \\
\text { иновий сік, } 40 \\
\text { за } \\
\text { вуглеводами }\end{array}$ & $\begin{array}{l}0,25 \Gamma / \Gamma \\
\text { біомаси }\end{array}$ & глюкоза - 109 & [21] \\
\hline & \begin{tabular}{|c|} 
Rhodospori- \\
dium toruloides \\
DSMZ 4444 \\
\end{tabular} & $\begin{array}{c}\text { глюкоза, } 30 \\
\text { гліцерин, } 30\end{array}$ & 11 г/л. & 一 & {$[22]$} \\
\hline & $\begin{array}{l}\text { Wickerhamo- } \\
\text { myces } \\
\text { anomalus }\end{array}$ & \begin{tabular}{|c|} 
глюкоза, $10+$ \\
відпрацьована \\
олія, 5 \\
(після \\
смаження \\
картоплі, риби \\
та м’яса) \\
\end{tabular} & 0,62 г/л & глюкоза - 103 & [23] \\
\hline & $\begin{array}{l}\text { Yarrowia } \\
\text { lipolytica } \\
\text { JMY4086 }\end{array}$ & \begin{tabular}{|c|} 
меляса, $245+$ \\
технічний \\
гліцерин, \\
$100^{* *}$ \\
\end{tabular} & 16 г/л & 一 & [24] \\
\hline & $\begin{array}{c}\text { Yarrowia } \\
\text { lipolytica } \text { SM7 }\end{array}$ & \begin{tabular}{|c|} 
технічний \\
гліцерин, $40+$ \\
оливкова олія, \\
$5(\%$ мас $)$ \\
\end{tabular} & 6,13 г/л & $\begin{array}{c}\text { гліцерин - } \\
117\end{array}$ & {$[32]$} \\
\hline Пулулан & $\begin{array}{c}\text { Aureobasidium } \\
\text { pululans } \\
201253\end{array}$ & $\begin{array}{c}\text { крохмаль, } 80+ \\
\text { сахароза, } 20\end{array}$ & 55 г/л & $\begin{array}{c}\text { крохмаль - } \\
157 \\
\text { сахароза }-79\end{array}$ & {$[25]$} \\
\hline Протеаза & $\begin{array}{c}\text { Aspergillus } \\
\text { oryzae TISTR } \\
3087\end{array}$ & \begin{tabular}{|c|} 
залишки \\
соєвих бобів + \\
відварений \\
рис (концен- \\
трація вугле- \\
водів 19,6 мг/г \\
субстрату) \\
\end{tabular} & 33 од/г & $\begin{array}{c}\text { соєві боби - } \\
1170\end{array}$ & [31] \\
\hline
\end{tabular}


BIOTECHNOLOGIES

Продовження табл. 2

\begin{tabular}{|c|c|c|c|c|c|}
\hline 1 & 2 & 3 & 4 & 5 & 6 \\
\hline Ліпаза & $\begin{array}{c}\text { Yarrowia } \\
\text { lipolytica SM7 }\end{array}$ & \begin{tabular}{|c|} 
технічний \\
гліцерин, $40+$ \\
соєва олія, 5 \\
$(\%$ мас $)$
\end{tabular} & 22,45 од/мЛ & $\begin{array}{c}\text { гліцерин - } \\
560\end{array}$ & [32] \\
\hline Біоетанол & $\begin{array}{c}\text { Enterobacter } \\
\text { aerogenes } \\
\text { ATCC } 29007\end{array}$ & $\mid \begin{array}{c}\text { манітолу, } 16+ \\
\text { гліцерин, } 20\end{array}$ & 32,1 г/л & $\begin{array}{c}\text { гліцерин - } \\
617\end{array}$ & {$[41]$} \\
\hline \multirow[b]{2}{*}{ Біоводень } & \begin{tabular}{|c|} 
Thermoanaero \\
bacterium \\
thermosaccha- \\
rolyticum \\
KKU-ED1 \\
\end{tabular} & $\begin{array}{l}\text { ксилоза, } 5+ \\
\text { арабіноза, } 5\end{array}$ & 3,5 л/л, & $\mid \begin{array}{c}\text { ксилоза - } 249 \\
\text { арабіноза - } \\
193\end{array}$ & [42] \\
\hline & $\begin{array}{l}\text { Консорціум } \\
\text { мікроорга- } \\
\text { нізмів }\end{array}$ & \begin{tabular}{|c|} 
технічний \\
гліцерин, $15+$ \\
жмих від \\
виробництва \\
пальмової олії, \\
2 (\% мас)
\end{tabular} & 0,27 л/л & $\begin{array}{c}\text { гліцерин - } \\
540\end{array}$ & [43] \\
\hline $\begin{array}{l}\text { Молочна } \\
\text { кислота }\end{array}$ & $\begin{array}{c}\text { Lactobacillus } \\
\text { casei } \text { CICC } \\
6106\end{array}$ & \begin{tabular}{|c|} 
жмих софори \\
жовтуватої \\
(Sophora fla- \\
vescens) 4 (\% \\
мас) + змішані \\
харчові відхо- \\
ди $6(\%$ мас) \\
\end{tabular} & 48,4 г/л & $\mid \begin{array}{c}\text { жмих } \\
\text { софори - } 480 \\
\text { харчові } \\
\text { відходи - } 133\end{array}$ & [34] \\
\hline $\begin{array}{l}\text { Пропіонова } \\
\text { кислота }\end{array}$ & \begin{tabular}{|c|} 
Propioni- \\
bacterium \\
acidipropionici \\
CGMCC1.2225
\end{tabular} & \begin{tabular}{|c|} 
гліцерин, 3,2 \\
$\%+$ \\
глюкоза, 0,8 \% \\
(об’ємна \\
частка) \\
\end{tabular} & 21,9 г/л & $\mid \begin{array}{c}\text { гліцерин - } \\
121 \\
\text { глюкоза - } 190\end{array}$ & [35] \\
\hline $\begin{array}{c}\text { Лимонна } \\
\text { кислота }\end{array}$ & $\begin{array}{c}\text { Yarrowia } \\
\text { lipolytica } \mathrm{SM} 7\end{array}$ & \begin{tabular}{|c|} 
технічний \\
гліцерин, $40+$ \\
оливкова олія, \\
5\% (об’ємна \\
частка) \\
\end{tabular} & 2,3 г/л & $\begin{array}{c}\text { гліцерин - } \\
192\end{array}$ & [32] \\
\hline Пропандіол & $\begin{array}{c}\text { Klebsiella } \\
\text { pneumoniae } \\
\text { BA11 }\end{array}$ & \begin{tabular}{|c|} 
гліцерин, 6\% + \\
глюкоза, 0,6\% \\
(об'ємна \\
частка)
\end{tabular} & 9,3 г/л & $\mid \begin{array}{c}\text { гліцерин - } \\
112 \\
\text { глюкоза - 930 }\end{array}$ & [39] \\
\hline $\begin{array}{c}\text { Полігідрокси- } \\
\text { алканоат }\end{array}$ & $\begin{array}{c}\text { Cupriavidus sp. } \\
\text { USMAA1020 }\end{array}$ & 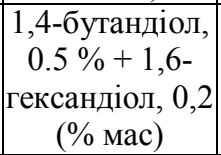 & 5,4 г/л & $\begin{array}{c}\text { 1,4-бутан } \\
\text { діол - } 340 \\
1,6-\text {-ексан } \\
\text { діол -675 }\end{array}$ & [28] \\
\hline
\end{tabular}

Примітки: *контроль (100\%) — показники синтезу на моносубстратах; ** — кінцева концентрація субстрату; «—»- дані не наведено.

\section{Висновок}

Отже, представлені результати показують доцільність використання суміші ростових субстратів для підвищення синтезу практично важливих 
мікробних метаболітів, а також засвідчують необхідність правильного вибору субстратів і коректного визначення молярного співвідношення їх концентрацій для забезпечення максимальної інтенсифікації процесу.

\section{Література}

1. Erickson B., Nelson J., Winters P. Perspective on opportunities in industrial biotechnology in renewable chemicals. Biotechnol. J. 2012, 7(2), 176-185. doi: 10.1002/biot.201100069.

2. Pidhorskyy V., Iutinska G., Pirog T. Intensification of microbial synthesis technologies. K.: Nauk. Dumka, 2010. 327 p. Ukrainian.

3. Pirog T.P., Shulyakova M.A., Shevchuk T.A. Mixed substrates in environment and biotechnological processes. Biotechnologia Acta. 2013, 6 (6), 2844. doi: 10.15407/biotech6.06.028. Ukrainian.

4. Vedaraman $N$., Venkatesh $N$. The effect of medium composition on the production of sophorolipids and the tensiometric properties by Starmerella bombicola MTCC 1910. Pol. J. Chem. 2010. 12(2), 9-13. doi:10.2478/v10026-010-0011-4.

5. Joshi-Navare K., Singh P.K., Prabhune A.A. New yeast isolate Pichia caribbica synthesizes xylolipid biosurfactant with enhanced functionality. Eur. J Lipid Sci. Technol. 2014. 116(8), 1070-1079. doi:10.1002/ej1t.201300363.

6. Ma X., Li H., Song X. Surface and biological activity of sophorolipid molecules produced by Wickerhamiella domercqiae var. sophorolipid CGMCC 1576. J. Colloid Interface Sci. 2012. 376(1), 165-172. doi:10.1016/j.jcis.2012.03.007.

7. Faria N. T., Santos M. V., Fernandes P., Fonseca L. L., Fonseca C., Ferreira F. C. Production of glycolipid biosurfactants, mannosylerythritol lipids, from pentoses and Dglucose/D-xylose mixtures by Pseudozyma yeast strains. Process Biochem. 2014. 49(11), 1790-1799. doi:10.1016/j.procbio.2014.08.004.

8. Souza, K.S.T., Gudiña, E.J., Azevedo, Z., de Freitas, V., Schwan, R.F., Rodrigues, L.R., Teixeira, J.A. New glycolipid biosurfactants produced by the yeast strain Wickerhamomyces anomalus CCMA 0358 . Colloids Surf. B: Biointerfaces. 2017, 154, 373-382. doi:10.1016/j.colsurfb.2017.03.041.

9. Karpenko I., Midyana G., Karpenko O., Novikov V. Influence of food industry wastes as substrates on the yield of biosurfactants of the strain Pseudomonas sp. PS-17. Ecol. Eng. Environ. Protec. 2016, 6, 44-51.

10. Rashad M.M., Nooman M.U., Ali M.M., Al-Kashe, A.S., Mahmoud, A.E. Production, characterization and anticancer activity of Candida bombicola sophorolipids by means of solid state fermentation of sunflower oil cake and soybean oil. Grasas Aceites. 2014, 65(2). doi: http://dx.doi.org/10.3989/gya.098413.

11. Rashad M.M., Al-Kashef A.S., Nooman M.U., El-din-Mahmoud A.E. Co-utilization of motor oil waste and sunflower oil cake on the production of new sophorolipids by Candida bombicola NRRL Y-17069. Res. J. Pharm. Biol. Chem. Sci. 2014, 5(4), 1515-1528.

12. Daverey A., Pakshirajan K. Sophorolipids from Candida bombicola using mixed hydrophilic substrates: production, purification and characterization. Colloids Surf. B. Biointerfaces. 2010, 79(1), 246-253. doi:10.1016/j.colsurfb.2010.04.002.

13. Maheshwari N., Kumar M., Thakur I.S., Srivastava S. Recycling of carbon dioxide by free air $\mathrm{CO}_{2}$ enriched (FACE) Bacillus sp. SS105 for enhanced production and optimization of biosurfactant. Bioresour. Technol. 2017, 242, 2-6. https://doi.org/10.1016/j.biortech.2017.03.124 .

14. Pirog T., Shevchuk T., Beregova K., Kudrya N. Intensification of surfactants synthesis under cultivation Nocardia vaccinii IMV B-7405 on a mixture of glucose and glycerol. Biotechnologia Acta. 2015, 8 (6), 23-31. doi: 10.15407/biotech8.06.023.

15. Pirog T.P., Kudrya N.V., Shevchuk T.A., Beregova K.A., Iutynska G.O. Bioconversion of crude glycerole and molasses mixture in biosurfactants of Nocardia vaccinii IMB B-7405. Mikrobiol. Z. 2015, 77(3), 28-35. Russian. doi: https://doi.org/10.15407/microbiolj77.03.028. 


\section{BIOTECHNOLOGIES}

16. Feng X., Walker T.H., Bridges W.C., Thornton C., Gopalakrishnan K. Biomass and lipid production of Chlorella protothecoides under heterotrophic cultivation on a mixed waste substrate of brewer fermentation and crude glycerol. Bioresour. Technol. 2014, 166, 17-23. doi: 10.1016/j.biortech.2014.03.120.

17. Martín M.A., Fernández R., Serrano A., Siles J.A. Semi-continuous anaerobic co-digestion of orange peel waste and residual glycerol derived from biodiesel manufacturing. Waste Manag. 2013, 33(7), 1633-1639. doi: 10.1016/j.wasman.2013.03.027.

18. Louhasakul $Y$., Cheirsilp B. Industrial waste utilization for low-cost production of raw material oil through microbial fermentation. Appl. Biochem. Biotechnol. 2013, 169(1), 110-122.

19. Liu J., Yuan M., Liu J.N., Huang, X.F. Bioconversion of mixed volatile fatty acids into microbial lipids by Cryptococcus curvatus ATCC 20509. Bioresour. Technol. 2017. 241, 645651. doi: 10.1016/j.biortech.2017.05.085.

20. Liu J., Yuan M., Liu J.N., Lu L.J., Peng K.M., Huang X.F. Microbial conversion of mixed volatile fatty acids into microbial lipids by sequencing batch culture strategy. Bioresour. Technol. 2016, 222, 75-81. doi: 10.1016/j.biortech.2016.09.100.

21. Ganatsios V., Koutinas A.A., Bekatorou A., Panagopoulo, V., Banat I.M., Terpou A. Kopsahelis $N$. Porous cellulose as promoter of oil production by the oleaginous yeast Lipomyces starkeyi using mixed agroindustrial wastes. Bioresour. Technol. 2017, 244, 629—634. doi: 10.1016/j.biortech.2017.07.163.

22. Bommareddy R.R., Sabra W., Zeng A.P. Glucose-mediated regulation of glycerol uptake in Rhodosporidium toruloides: insights through transcriptomic analysis on dual substrate fermentation. Engineering in Life Sciences. 2017, 17(3), 282-291. https://doi.org/10.1002/elsc.201600010.

23. Arous F., Atitallah I.B., Nasri M., Mechichi T. A sustainable use of low-cost raw substrates for biodiesel production by the oleaginous yeast Wickerhamomyces anomalus. 3 Biotech. 2017, 7(4):268. doi: 10.1007/s13205-017-0903-6.

24. Rakicka M., Lazar Z., Dulermo T., Fickers P., Nicaud J.M. Lipid production by the oleaginous yeast Yarrowia lipolytica using industrial by-products under different culture conditions. Biotechnol. Biofuels. 2015, 8:104. doi: 10.1186/s13068-015-0286-z.

25. An C., Ma S.J., Chang F., Xue W.J. Efficient production of pullulan by Aureobasidium pullulans grown on mixtures of potato starch hydrolysate and sucrose. Braz. J. Microbiol. 2017, 48(1), 180-185. doi: 10.1016/j.bjm.2016.11.001.

26. Xu Y., Coda R., Shi Q., Tuomainen P., Katina K., Tenkanen M. Exopolysaccharides production during the fermentation of soybean and fava bean flours by Leuconostoc mesenteroides DSM 20343. J. Agric. Food Chem. 2017, 65(13), 2805-2815. doi: 10.1021/acs.jafc.6b05495.

27. Pirog T.P., Voronenko A.A.,. Ivakhniuk M.O. Intensification of microbial exopolysaccharide ethapolan biosynthesis on mixture of molasses and sunflower oil. Biotechnologia Acta, 2017, V. 10, N 4. C. 25-33. https://doi.org/10.15407/biotech10.04.025.

28. Huong K., Mohd Yahya A.R., Amirul A.A. Pronounced synergistic influence of mixed substrate cultivation on single step copolymer $\mathrm{P}(3 \mathrm{HB}-\mathrm{co}-4 \mathrm{HB})$ biosynthesis with a wide range of 4HB monomer composition. J. Chem. Technol. Biotechnol. 2014. 89(7), 1023-1129. https://doi.org/10.1002/jctb.4195

29. Huong K.H., Kannusamy S., Lim S.Y., Amirul A.A. Biosynthetic enhancement of single-stage Poly(3-hydroxybutyrate- $\mathrm{co}^{-4}$-hydroxybutyrate) production by manipulating the substrate mixtures. J. Ind. Microbiol. Biotechnol. 2015, 42(9), 1291-1297. doi: 10.1007/s10295-015-1657-y.

30. Syafiq I.M., Huong K.H., Shantini K. Synthesis of high 4-hydroxybutyrate copolymer by Cupriavidus sp. transformants using one-stage cultivation and mixed precursor substrates strategy. Enzyme Microb. Technol. 2017, 98, 1-8. doi: 10.1016/j.enzmictec.2016.11.011.

31. Salakkam A., Kingpho Y., Najunhom S., Aiamsonthi K., Kaewlao S., Reungsang A. Bioconversion of soybean residue for use as alternative nutrient source for ethanol fermentation. Biochem. Eng. J. 2017, 125, 65-72. https://doi.org/10.1016/j.bej.2017.05.020. 
32. Magdouli S., Guedri T., Tarek R., Brar S.K., Blais J.F. Valorization of raw glycerol and crustacean waste into value added products by Yarrowia lipolytica. Bioresour. Technol. 2017, 243, 57-68. doi: 10.1016/j.biortech.2017.06.074.

33. Kumari A., Satyanarayana T., Singh B. Mixed substrate fermentation for enhanced phytase production by thermophilic mould Sporotrichum thermophile and its application in beneficiation of poultry feed. Appl. Biochem. Biotechnol. 2016, 178(1), 197-210. doi: 10.1007/s12010-015-1868-8.

34. Zheng J., Gao M., Wang Q., Wang J., Sun X., Chang Q., \& Tashiro Y. Enhancement of 1lactic acid production via synergism in open co-fermentation of Sophora flavescens residues and food waste. Bioresour. Technol. 2017, 225, 159-164. doi: 10.1016/j.biortech.2016.11.055.

35. Liu Y.G., Zhang R.B., Zhang F., Zhang J. Zhu J. Glycerol/glucose co-fermentation: one more proficient process to produce propionic acid by Propionibacterium acidipropionici. Curr. Microbiol. 2011, 62(1), 152-158. doi: 10.1007/s00284-010-9683-5.

36. Cao W., Liu B., Luo J., Yin J., Wan Y. $\alpha, \omega$-Dodecanedioic acid production by Candida viswanathii ipe-1 with co-utilization of wheat straw hydrolysates and n-dodecane. Bioresour. Technol. 2017, 243, 179-187. doi: 10.1016/j.biortech.2017.06.082.

37. Podleśny M., Jarocki P., Wyrostek J., Czernecki T., Kucharska J., Nowak A., Targoński Z. Enterobacter sp. LU1 as a novel succinic acid producer - co-utilization of glycerol and lactose. Microb. Biotechnol. 2017, 10(2), 492-501. doi: 10.1111/1751-7915.12458.

38. Kowalczyk S., Komoń-Janczara E., Glibowska A., Kuzdraliński A., Czernecki T., Targoński Z. A co-utilization strategy to consume glycerol and monosaccharides by Rhizopus strains for fumaric acid production. AMB Express. 2018, 8(1):69, doi: 10.1186/s13568-0180601-8.

39. Sen B., Dabir A.P., Lanjekar V.B., Ranade D.R. Isolation and partial characterization of a new strain of Klebsiella pneumoniae capable of high 1,3 propanediol production from glycerol. Global J. Environ. Sci. Manage. 2015, 1(2), 99-108. doi: 10.7508/gjesm.2015.02.001.

40. Xin B., Wang Y., Tao F., Li L., Ma C., Xu P. Co-utilization of glycerol and lignocellulosic hydrolysates enhances anaerobic 1,3-propanediol production by Clostridium diolis. Sci. Rep. 2016, 6. doi: 10.1038/srep19044.

41. Thap L.P., Le S.J., Yang X.G., Yoo H.Y., Kim S.B., Park C., Kim S.W. Co-fermentation of carbon sources by Enterobacter aerogenes ATCC 29007 to enhance the production of bioethanol. Bioprocess. Biosyst. Eng. 2014, 37(6), 1073-1084. doi: 10.1007/s00449-013-1079-z.

42. Saripan A.F., Reungsang A. Biohydrogen production by Thermoanaerobacterium thermosaccharolyticum KKU-ED1: Culture conditions optimization using mixed xylose/arabinose as substrate. Electronic J. Biotechnol. 2013, 16(1), doi: 10.2225/vol16-issue1-fulltext-1.

43. Kanchanasuta S., Pisutpaisal N. Improvement of glycerol waste utilization by co-feedstock with palm oil decanter cake on biohydrogen fermentation. Int. J. Hydrogen Energ. 2017, 42(5), 3447-3453. doi:10.1016/j.ijhydene.2016.12.134. 